\title{
Morphological abnormalities in Cladocera (Branchiopoda) in a cascade of reservoirs in the middle and lower Tietê river (São Paulo, Brazil)
}

\author{
Zanata, LH. ${ }^{\mathrm{a}}$, Espíndola, ELG. ${ }^{\mathrm{a} *}$, Rocha, O. ${ }^{\mathrm{b} *}$ and Pereira, RHG. ${ }^{\mathrm{c} *}$ \\ aNúcleo de Estudos de Ecossistemas Aquáticos, Centro de Recursos Hídricos e Ecologia Aplicada, \\ SHS, EESC, Universidade de São Paulo - USP \\ Av. Trabalhador São-carlense, 400, CP 292, CEP 13560-970, São Carlos, SP, Brazil

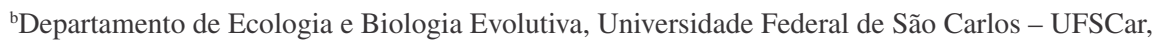 \\ CP 676, CEP 13565-905, São Carlos, SP, Brazil \\ ${ }^{\mathrm{c}}$ Centro Universitário de Aquidauana, Universidade Federal de Mato Grosso do Sul - UFMT, \\ CEP 79200-000, Aquidauana, MS, Brazil \\ *e-mail: elgaeta@sc.usp.br, doro@power.ufscar.br, ricardo@ceua.ufms.br \\ Received May 02, 2008 - Accepted May 30, 2008 - Distributed August 31, 2008
}

(With 2 figures)

Morphological abnormalities in Cladocera were found in cascading reservoirs of the middle and lower Tietê River (São Paulo State, Brazil). These alterations occurred at the ventral margin of the carapace in Daphnia gessneri, D. laevis, D. ambigua, D. lumholtzi, Ceriodaphnia silvestrii and C. cornuta and in the helmet and rostrum of Daphnia. These abnormalities may have been caused by chemical contaminants or microorganisms like bacteria and viruses, linked to evidence of pollution in areas of the environment studied (Montú and Gloeden, 1982; Dias, 1999; Otha et al., 1998). In 1993, Hanazato and Dodson showed that four species of Daphnia (D. pulex, D. galeata mendotae, D. lumholtzi, and $D$. retrocurva) present morphological alterations in response to the presence of carbaryl insecticide.

In the Tietê River, the presence of toxic substances has been demonstrated by various authors. Calheiros (1993) verified contamination in Barra Bonita reservoir by persistent organochlorine compounds. Toxicity tests carried out in the Tietê River prove the presence in aquatic environmental of harmful substances, like cadmium, iron, copper, lead, and manganese; verified by Costa (2001), Fracácio (2001) and Rodgher et al. (2003).

The results presented in this study were obtained by analyzing samples from 19 stations distributed along a cascading system on the middle and lower Tietê River, taken in February, May, July, and October of 2000. They revealed organisms presenting various stages of abnormality, of which the greatest density was found in the D. gessneri population (Figure 1). The total density of $D$. gessneri presenting morphological alterations in the carapace varied from 160 ind. $\mathrm{m}^{-3}$ (July 2000) to 387 ind. $\mathrm{m}^{-3}$ (May 2000). Percentages of occurrence of these alterations in D. gessneri in relation to the total amount of healthy organisms of the same species varied from $0.03 \%$ (5 ind. $\mathrm{m}^{-3}$ ) (Tietê River, May 2000; Ibitinga dam, October 2000) to $6.85 \%$ (40 ind. $\mathrm{m}^{-3}$ ) (Três Irmãos reservoir, July 2000). D. laevis ranked second in density of deformed organisms, with a maximum of 54 ind. $\mathrm{m}^{-3}$
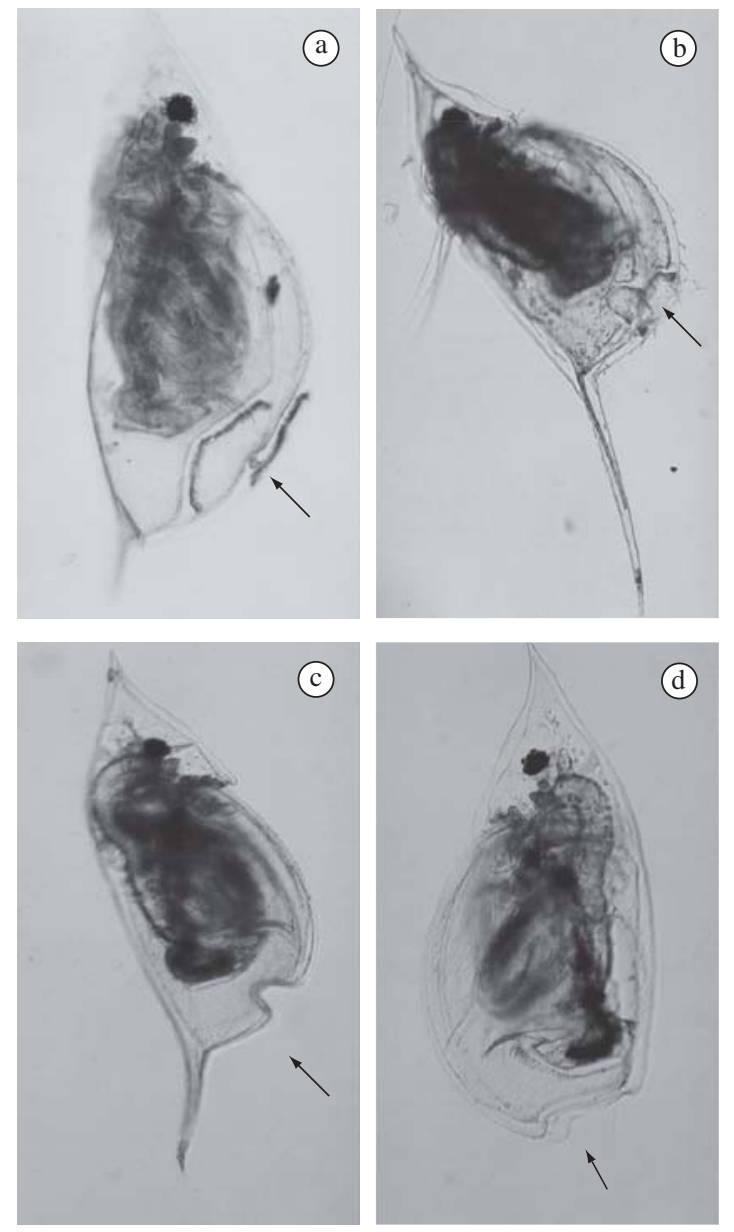

Figure 1. Morphological alterations in the carapace of Daphnia (x100); observed in samples obtained in 2000 from the reservoir cascade on the Tietê River (São Paulo, Brazil). a) D. laevis; b) D. lumholtzi; c and d) D. gessneri. (Photos taken by the author.) 
registered in October 2000 (45 ind. $\mathrm{m}^{-3}$ in Barra Bonita reservoir; 9 ind. $\mathrm{m}^{-3}$ in Promissão reservoir). D. lumholtzi was also found with carapace alterations at a rate of 15 ind. $\mathrm{m}^{-3}$. In addition to these organisms, Daphnia ambigua and species of Ceriodaphnia also presented deformations, although at a lesser density and less frequently.

The appearance of the affected organisms suggested that the deformed tissue had resulted from invasion (Figure 1). To determine the cause, the DAPI method (Porter and Feig, 1980) was applied, which in addition to the use of an epifluorescent microscope, would reveal possible bacterial presence in the affected areas. The result was negative.

The second instance of morphological alterations was found only in individuals of the genus Daphnia, which presented alterations of varied appearance, confined to the helmet and rostrum (Figure 2). These organisms were found only in the Bariri reservoir $\left(10\right.$ ind. $\left.\mathrm{m}^{-3}\right)$ and at the entrance of the dam of the Três Irmãos reservoir $\left(5\right.$ ind. $\left.\mathrm{m}^{-3}\right)$ in February and October of 2000. This alteration may have been congenital. According to Elmoor-Loureiro (2004), who demonstrated malformations in the post-anal spines and terminal claws of Ilyocryptus spinifer, the causes of morphological abnormalities in microcrustaceans have not yet been adequately investigated.

Acknowledgements - The authors are grateful to CNPq for the $\mathrm{PhD}$ grant to the first author, and to FAPESP (BIOTA Program
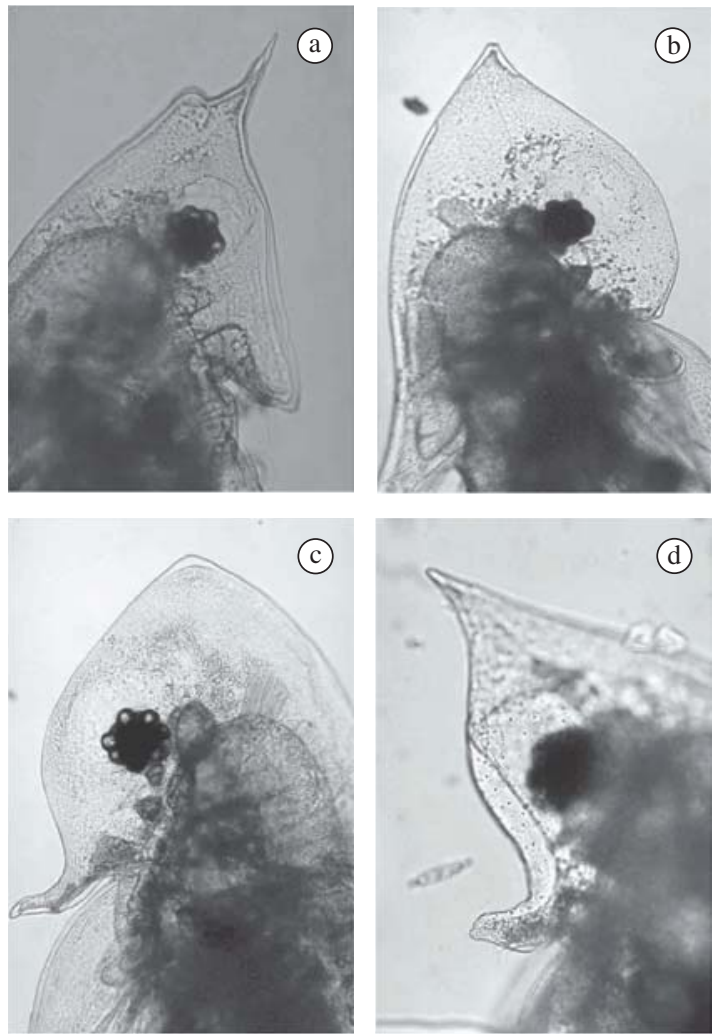

Figure 2. Morphological alterations on the head of Daphnia (a, b, c and d) (x 250); observed in samples obtained in 2000 from São Paulo, Brazil. (Photos taken by the author.) and to Ministry of Environment and National Research Council, (PROBIO Program - MMA/CNPq/BIRD/GEF) for financial support of the "Monitoring and development of technologies for managing freshwater exotic species" Project. They also thank Magno Botelho Castelo Branco, for valuable assistance in image processing, as well as Mirna Helena Regali-Seleghim and Silvia Fatibello for help with DAPI analysis.

\section{References}

CALHEIROS, DF., 1993. Ecotoxicologia de compostos organoclorados persistentes em um ecossistema eutrófico: Represa de Barra Bonita (Médio Tietê, SP). São Carlos: Escola de Engenharia de São Carlos, Universidade de São Paulo. 198 p. [Dissertação de Mestrado].

COSTA, JB., 2001. Avaliação ecotoxicológica da água e sedimento de tributários do reservatório de Barra Bonita (Médio Tietê Superior, SP). São Carlos: Escola de Engenharia de São Carlos, Universidade de São Paulo. 244 p. [Dissertação de Mestrado].

DIAS, CO., 1999. Morphological abnormalities of Acartia lilljeborgi (Copepoda, Crustacea) in the Espírito Santo Bay, ES, Brazil. Hydrobiologia., vol. 394, no. 1, p. 249-251.

DODSON, S., MERRITT, CM., SHANNAHAN, J. and SHULTS, C., 1999. Low exposure concentrations of Atrazine increase male production in Daphnia pulicaria. Environ. Toxicol. Chem, vol. 18, no. 7, p. 1568-1573.

ELMOOR LOUREIRO, LMA., 2004. Morphological abnormalities in the cladoceran Ilyocryptus spinifer (Apipucos reservoir, Pernambuco State, Brazil). Rev. Bras. Biol. $=$ Braz. J. Biol., vol. 64, no. 1, p. 53-58.

FRACÁCIO, R., 2001. Utilização de bioensaios ecotoxicológcos com Danio rerio (Cypriniforme, Cyprinidae) e análises limnológicas para a avaliação ambiental dos reservatórios do Médio e Baixo Tietê (SP). São Carlos: Escola de Engenharia de São Carlos, Universidade de São Paulo. 233 p. [Dissertação de Mestrado].

HANAZATO, T., 1991. Pesticides as chemical agents inducing helmet formation in Daphnia ambigua. Freshwater Biol., vol. 26 , no. 3, p. 419-424.

HANAZATO, T. and DODSON, S., 1993. Morphological responses of four species of cyclomorphic Daphnia to a shortterm exposure to the insecticide carbaryl. J. Plankton Res., vol. 15 , no. 9 , p. 1087-1095.

MONTÚ, M. and GLOEDEN, I., 1982. Morphological alterations in Acartia tonsa (Saco da Mangueira, Lagoa dos Patos, Brazil). Arq. Biol. Tecnol., vol. 25, no. 3-4, p. 361-369.

OTHA, T., TOKISHITA, S., SHIGA, Y., HANAZATO, T. and YAMAGATA, H., 1998. An assay system for detecting environmental toxicants with cultured cladoceran eggs in vitro: malformations induced by Ethylenethiourea. Environ. Res., vol. 77 , no. 1 , p. $43-48$

PORTER, K. and FEIG, Y., 1980. The use of DAPI for identifying and counting aquatic microflora. Limnol. Oceanog., vol. 25 , no. 5 , p. $943-948$.

RODGHER, S., 2001. Estudos ecotoxicológicos e limnológicos nos reservatórios em cascata do Médio e Baixo Rio Tietê: uma análise espacial e temporal. São Carlos: Escola de Engenharia de São Carlos, Universidade de São Paulo. 213 p. [Dissertação Mestrado].

RODGHER, S., ESPÍNDOLA, ELG., ROCHA, O., FRACÁCIO, R., PEREIRA, RHG. and RODRIGUES, MHS., 2003. Ecotoxicological analysis of the water and sediment from middle and low Tietê river cascade reservoirs (São Paulo State, Brazil). Acta Limnol. Bras., vol. 15, no. 3, p. 81-93. 